\title{
FOREIGN DIRECT INVESTMENT AND TECHNOLOGICAL INNOVATION IN DEVELOPING COUNTRIES
}

\author{
Kamilia Loukil \\ Department of Economics, Faculty of Econonomics and Management of Sfax, Tunisia \\ loukilkamilia2005@yahoo.fr
}

\begin{abstract}
A large number of countries have enacted laws aimed at making it easier for firms to invest in their country, while many countries offer various monetary incentives and tax incentives to encourage inward Foreign Direct Investment (FDI). The desire to attract FDI is due not only to the fact that FDI brings in new investment boosting national income and employment, but also due to the expectation that inward FDI would also provide additional spillover benefits to the local economy that can result in higher productivity growth and increased export growth. This study aims to examine the impact of foreign direct investment on innovation in developing countries. The estimation of a panel threshold model on a sample of 54 developing countries for the 1980-2009 period shows the presence of non linear effects in the relationship between FDI and innovation. We find a threshold value of technological development below which FDI has a negative impact on innovation and above which FDI has a significant positive impact on innovation. We conclude that it is not enough for economic policy to attract foreign investments, it is still necessary to support domestic firms to build an absorptive capacity allowing them to enjoy the benefits of multinational firms.
\end{abstract}

Keywords: foreign direct investment; innovation; absorptive capacity; non linear relationship.

JEL Classification: 03.

\section{Introduction}

Theoretical contributions have long established that innovation promotes economic development (e.g., Aghion and Howitt, 1992; Romer, 1990). The empirical evidence similarly suggests that technological progress, national innovative capacity and the productivity gains associated with innovation are important sources of economic growth (e.g., Geroski, 1989; Fagerberg et. al., 2007). Due to the beneficial role of technological progress in economic growth and development, further scholarly contributions have set out to identify the national determinants of innovation. These studies have found that innovation is not only positively influenced by factors directly associated with the generation of new knowledge such as R\&D spending, the quality of education and specialization in industrial clusters but also by a nation's common innovation infrastructure, i.e., the economic and institutional environment (Grilliches, 1990; Aghion, 2004; Furman et. al., 2002; Varsakelis, 2006).

In this contribution we examine an economic element of a nation's innovation infrastructure: the Foreign Direct Investment (FDI). Indeed, a number of theoretical contributions emphasize the benecial effect of foreign investment on innovation and, ultimately, economic growth (Berger and Diez, 2008; Blomstrom and Kokko, 2002). Foreign investment is assumed to affect the domestic economy by bringing in much needed capital, new technologies, marketing techniques and management skills, and by bringing in secondary spillovers to the host economy that affects the performance of domestic firms. Such spillovers can arise due to the leakage of the MNCs proprietary knowledge or due to the 
response of domestic firms to the arrival of foreign firms. Such spillovers -if present- are likely to affect the productivity of domestic firms in the same industry, but can also have effects on wages and market access, as well as productivity in upstream and downstream industries.

Due to the increasing importance of FDI, an empirical literature has developed examining its impact on economic performance in the host economy. Our study aims to enrich existing literature by examining the impact of FDI on innovation for 54 countries between 1980 and 2009. We suppose the presence of non linear effects in the relation FDI / innovation and estimate a panel threshold model developed by Hansen (1999). Our findings show that foreign investment allows to stimulate innovation only in countries with a high level of technological development. In sum, our findings suggest that economic policy should support domestic firms to build an absorptive capacity in order to enjoy the benefits of Multinational Companies.

This paper is organized as follows. In Section 2 we discuss the linkages between foreign direct investment and national innovative activity. In Section 3 we introduce the data and empirical methodology. Our empirical findings are presented and discussed in Section 4. Section 5 concludes.

\section{Survey of the Literature}

FDI may influence the technological innovation in host countries through several mechanisms: backward linkages, forward linkages, competitive effect, demonstration effect, effects on human capital formation and dissemination of knowledge through brain (Berger and Diez, 2008).

- Backward linkages

Multinational Companies (MNC) will provide inputs and services from domestic sources. These links are considered good opportunities for spillovers of MNC (Altenburg, 2000). In this case, the subsidiaries of MNCs provide information on international quality standards and can even support local providers through financial assistance, technology transfer, training and sharing of information and knowledge (UNCTAD, 2001).

- Forward linkages

Subsidiaries of the MNC sell products to domestic customers inducing therefore the knowledge transfer (especially in case of sale of capital equipment) through offering training in order to learn the operation and maintenance of the equipment.

- The competitive effect

MNC often enter domestic markets and compete with local firms. This can motivate domestic firms to increase their efforts to improve technologies which allow them to increase competitiveness. However, this competitive effect can threaten domestic firms to be driven from the market (crowding out effect).

- The demonstration effect

Subsidiaries of MNCs are distinguished by the high quality of their technology and management practices. Domestic companies are likely to benefit if they proceed to the observation, copying and adaptation of these technologies and practices.

- The effects on human capital formation

Subsidiaries are related to national research and education institutions to ensure an adequate supply of human resources. In this case, the MNC offer funding to students and access to new technologies (Blomstrom and Kokko, 2002). Furthermore, employment opportunities in the subsidiaries of MNCs may encourage students to choose science and technology streams. As long as MNC do not absorb all the graduates, this can increase the availability of highly skilled labor. 
- The dissemination of knowledge through the staff mobility

MNC are characterized by the use of advanced technologies and the application of modern management practices. Their staff learns by doing and receive additional training in order to meet the skills requirements. Thanks to the mobility of labor, knowledge and skills are disseminated in the host economy (Altenburg, 2000). In addition, former employees can use this knowledge to establish their own businesses, thus enriching the economic structure (UNCTAD, 2001).

However, technological spillovers generated by foreign firms to domestic firms may be lower than expected. Indeed, sometimes MNC are not willing to transfer the most advanced technology because they fear the loss of intellectual property and future competition of companies that learn new technologies (Hayter and Han, 1998). From the perspective of the MNC, it will be rational to transfer the most obsolete technology. These old technologies have additional benefits. They are less complicated and require less skilled employees in the host country, they are less expensive and easier to explain.

The limits of success of technology transfer from MNC also exist on the side of the host country. In fact, technological capabilities of the beneficiary companies in developing countries and skills of their employees often prevent immediate understanding of advanced technologies (Cohen and Levinthall, 1990). In addition, communication barriers (various languages and ways of individual interaction) may impede the efficient transfer of technology.

Given these arguments, it is not surprising that despite the possible benefits from international technology transfer, the results of empirical works on the impact of FDI on innovation are mixed. In what follows, we review literature according to three groups of studies: those which find positive effects, those which find negative effects and those which show a non linear effects in the relationship between FDI and innovation.

In the first group, we cite the study of Sjoholm (1999) who shows that FDI is beneficial for companies in Indonesia. Cheung and Lin (2004) found positive effects of FDI on the number of patents in China. Using data on Japanese FDI into the United States, Branstetter (2001) finds evidence that FDI encourages technology spillovers through subsidiaries bringing technology from their countries of origin and through MNCs facilitating learning of foreign technologies. Keller and Yeaple (2009) using data on US manufacturing firms over the period 1987-1996 show that spillovers from foreign multinationals to US firms can explain a significant part of US manufacturing productivity growth. Kokko (1996) and Driffield (1999) find evidence of positive competition effects for Mexico and the UK respectively.

By contrast, in the second group of papers, Aitken and Harrison (1999) found that foreign participation in the capital of the company in Venezuela is positively correlated with productivity in the case of small businesses only. However, they did not find spillovers effects associated with joint ventures for companies without foreign participation with lower productivity due to FDI. Chen (2007) also showed that spillovers effects in China are not as significant as he thought. Indeed, he found that the impact of FDI on regional innovation capacity is weak: The entry of FDI is not important in improving indigenous innovation capacity. Furthermore, inflows of FDI can have effects of crowding out on innovation and national R\&D activity. Using the population of UK manufacturing firms, Haskel et. al., (2007) find that spillovers are positive and economically significant along industry lines, but find no significant evidence of spillovers occurring along regional lines.

The third group of studies state that technology transfer through FDI requires absorptive capacity of host nations. Absorptive capacity of a firm is "the ability to recognize the value of new information, assimilate it, and apply it to commercial ends" (Cohen and Levinthal, 1990: 128). Monastiriotis and Alegria (2011) find a significant effect of technological distance between investing nation and host nation, and internalization capacity of host nation in the processes of technology transfer via FDI. Yokota and Tomohara (2010) report that 
technology transfer through FDI is related to host countries' skilled work force capital. Similarly, Sinani and Klaus (2004) investigate the relationship between foreign presence and productivity through host nation's human capital and emphasize human capital's catalyst effect to this association. Xu (2000) provides a study comparing FDI impacts caused by US multinational enterprises on a host country's national productivity level between developed and developing countries. After performing a longitudinal analysis using the data collected from 40 countries from 1966 to 1994 in which US MNEs have been operating, she finds that US MNC contributes to the productivity growth in developed countries but not in low developed countries.

Considering the literature review above, we suppose a non linear relationship between FDI and innovation. We assume that the impact of foreign investment inflows on innovation depends on the nation's absorptive capacity.

\section{Methodology}

\subsection{Sample description}

Our sample includes 54 developing countries: Algeria, Argentina, Bangladesh, benin, Bolivia, Brazil, Burundi, Cameroon, Chile, Colombia, Congo, Costa Rica, Dominican Republic, Equador, Egypt, El Salvador, Fiji, Gabon, Ghana, Guatemala, Haiti, Honduras, Indonesia, Iran, Jamaica, Jordan, Kenya, Malawi, Malaysia, Mali, Maurice, Mexico, Morocco, Nepal, Nicaragua, Niger, Pakistan, Panama, Paraguay, Perou, Philippines, Senegal, Sierra Leone, South Africa, Sri Lanka, Syria, Thailand, Tunisia, Turkey, Uganda, Uruguay, Venezuela, Zambia, Zimbabwe.

The study uses data for 6 periods: 1980-1985; 1985-1990; 1990-1995; 1995-2000; 2000-2005; 2005-2009.

\subsection{Data}

We have collected variables in every 5 years for the 1980-2009 period.We use the number of patent applications filed in US Patent and Trademark Office (USPTO) as a measure of innovation, denoted by PAT. To measure foreign direct investment, we use the share of FDI inflows in GDP (FDI). Data are from Word Development Indicators. The absorptive capacity is measured by the level of technological development. We use per capita GDP, denoted by GDP. The data on PPP converted GDP per capita, at 2005 constant prices come from Penn World Table.

Three control variables are used in this study: human capital, institutions and country's size. The new growth theories are considered the most significant to explain innovation and economic growth at the macro level by the human capital factor (Aghion and Howitt, 1998). Furman et. al. (2002), Ulku (2007) and Gumbau Albert and Maudos (2009) found a positive relationship between levels of human capital and innovation.

To measure human capital stock, we use the variable EDUC: It's the educational attainment for population aged 15 and over at the secondary level. These ratios are collected from Barro and Lee database.

Sala-i-Martin (2002) argues that it is difficult to create new and better technologies if an economy has not good institutions. Mahagaonkar (2008) shows a negative relationship between corruption and innovation.Tebaldi and Elmslie (2013) confirmed a positive link between the quality of economic institutions and innovation.

We have data on measures of economic freedom, EF, from Fraser Institut. The freedom index ranges from 0 to 10, with a higher index indicating a higher level of economic freedom. Pritchett (1996) recognizes four reasons why a large population could be useful for the increasing of productivity: innovation by population pressures, b) innovation produced by greater numbers, c) scale economies, d) agglomeration economies. Lerner (2002), Furman 
et. al. (2002) and Chen and Puttitanun (2005) found a positive impact of country size on technological innovation.

The size of country is measured by number of population POP. Data for this variable are from Word Development Indicators.

Variables PAT, GDP and POP are in natural logarithme. Qualitative variables and those expressed as a percentage are not transformed in log (Furman et. al., 2002).

Summary statistics for the six variables are given in Table 1.

Table 1: Summary statistics

\begin{tabular}{|l|l|l|l|l|l|}
\hline & \multicolumn{1}{|c|}{ Mean } & \multicolumn{1}{c|}{ Median } & Stand. dev & Minimum & Maximum \\
\hline PAT & 17,61 & 2 & 49,584 & 0 & 383,4 \\
\hline FDI & 1,845 & 1,229 & 2,351 & $-5,281$ & 20,906 \\
\hline GDP & 4065,17 & 3449,651 & 3019,9 & 310,92 & 12283,29 \\
\hline EDUC & 26,62 & 25,65 & 14,368 & 1,6 & 72,5 \\
\hline EF & 5,539 & 5,592 & 1,164 & 1,781 & 7,921 \\
\hline POP & 29262035,3 & 12779953,6 & 40862784 & 668032,8 & 232328289 \\
\hline
\end{tabular}

\subsection{Panel Threshold Model}

According to Hansen (1999), a threshold model with $r$ regimes is defined as follow:

$\mathrm{Y}_{\mathrm{it}}=\alpha_{\mathrm{i}}+\beta \mathrm{X}+\delta_{1} \mathrm{c}_{\mathrm{it}} \mathrm{I}\left(\mathrm{d}_{\mathrm{it}} \leq \mathrm{Y}_{1}\right)+\delta_{2} \mathrm{c}_{\mathrm{it}} \mathrm{I}\left(\mathrm{Y}_{1}<\mathrm{d}_{\mathrm{it}} \leq \mathrm{Y}_{2}\right)+\ldots \delta_{\mathrm{r}} \mathrm{c}_{\mathrm{it}} \mathrm{I}\left(\mathrm{Y}_{\mathrm{r}-1}<\mathrm{d}_{\mathrm{it}}\right)+\varepsilon_{\mathrm{it}}$

où $\gamma_{1}<\gamma_{2}<\ldots<\gamma_{r-1}$.

For the purpose of the present study, we construct the single threshold model as follows:

$Y_{i t}=\alpha_{i}+\beta X+\delta c_{i t}{ }^{*} I\left(d_{i t} \leq y\right)+\theta c_{i t}{ }^{*} I\left(d_{i t}>y\right)+\varepsilon_{i t}$

$Y_{i t}$ represents dependant variable (PAT), $c_{i t}$ is foreign direct investment, $d_{i t}$ is the threshold variable: the level of technological development (GDP); and $\mathrm{Y}$ is the estimated threshold value. $X$ is a vector of four variables: GDP, EDUC, EF, POP. $\alpha_{i}$ : the fixed effect which represents the heterogeneity of companies under different operating conditions. I(.) is an indicator function. The error term $\varepsilon_{\text {it }}$ is independent and identically distributed with zero mean and finite variance $o^{2}$. The subscript $i$ stands for the cross-sections $(i=1,2, \ldots 54)$ and $t$ indexes time $(t=1,2, \ldots 6)$. Specification (2) highlights two regimes: one regime for which the variable $d_{i t}$ is less than or equal to the threshold $y$ and a second regime for which the variable $\mathrm{d}_{\mathrm{it}}$ is greater than the threshold $\mathrm{y}$. Our equation (2) can be rewritten as follows:

$\begin{cases}Y_{i t}=\alpha_{i}+\beta X+\delta d_{i t} & \text { si } d_{i t} \leq Y \\ Y_{i t}=\alpha_{i}+\beta X+\theta d_{i t} & \text { si } d_{i t}>Y\end{cases}$

To estimate this model, we first eliminate the individual effect $\alpha_{i}$ using the within transformation estimation techniques in the traditional fixed effect model of panel data. By using the ordinary least squares and minimizing the concentrated sum of squares of errors,

$\mathrm{S} 1(\mathrm{y})$, we can obtain the estimators of our threshold value and the residual variance, $\hat{\gamma}$ and ô2, respectively.

The second step will consist in testing the null hypothesis of linearity, $\mathrm{HO}: \delta=\theta$ which can be based on the likelihood ratio test:

$\mathrm{F} 1=(\mathrm{S} 0-\mathrm{S} 1(\hat{\gamma})) / \hat{\mathrm{o}} 2$,

$\mathrm{S} 0$ is the sum of squared errors under $\mathrm{HO}$ and $\mathrm{S} 1$ the sum of squared residuals under $\mathrm{H} 1$. However, as the asymptotic distribution of $\mathrm{F} 1$ is non standard, we use the procedure of bootstrap to construct the critical values and $p$-value.

Upon the existence of threshold effect, $\mathrm{HO}: \delta=\theta$, we should test for the asymptotic distribution of threshold estimate, $\mathrm{HO}: \mathrm{Y}=\mathrm{Y}_{0}$, and adopt the likelihood ratio test: 
$\mathrm{LR} 1(\mathrm{Y})=(\mathrm{S} 1(\mathrm{Y})-\mathrm{S} 1(\hat{\gamma})) /$ ô2 with the asymptotic confidence intervals:

$c(\alpha)=-2 \log (1-\sqrt{1-\alpha})$.

The panel threshold model is estimated by the computer program Matlab 2012.

\section{Findings}

Table 2 presents the test statistics F1, F2, and F3, along with their bootstrap p-values. It shows that the tests for a double threshold F2 and a triple threshold F3 are insignificant with a bootstrap $p$-value of 0,2 and 0,545 respectively. Only the test for a single threshold $\mathrm{F} 1$ is significant with a bootstrap $p$-value of 0,035 . Thus, we conclude that foreign direct investments have only one threshold effect on country innovation.

The point estimate of the threshold $(\hat{\gamma})$ is 5620,486 PPP and his asymptotic confidence interval is $[4547,862 ; 5885,592]$.

Table 2: Tests for threshold effects

\begin{tabular}{|l|l|}
\hline Single threshold effect test & 5620,486 \\
\hline Threshold value & 25,571 \\
\hline F1 & 0,035 \\
\hline P-value & $(16,2 ; 20,4 ; 32,2)$ \\
\hline (Critical value of F $10 \%, 5 \%, 1 \%)$ & 812,$378 ; 5620,486$ \\
\hline Double threshold effect test & 12,063 \\
\hline Threshold values & 0,2 \\
\hline F2 & $(16,6 ; 20,4 ; 26,3)$ \\
\hline P-value & \\
\hline (Critical value of F $10 \%, 5 \%, 1 \%)$ & 594,$272 ; 812,378 ; 5620,486$ \\
\hline Triple threshold effect test & 5,583 \\
\hline Threshold values & 0,545 \\
\hline F3 & $(12,6 ; 14,6 ; 15,8)$ \\
\hline P-value & \\
\hline (Critical value of F $10 \%, 5 \%, 1 \%)$ &
\end{tabular}

More information can be learned about the threshold estimate from plot of the concentrated likelihood ratio function LR1( $\mathrm{Y}$ ) in Figure 1. 
Figure 1 LConfidence Interval Construction in Single Threshold Model

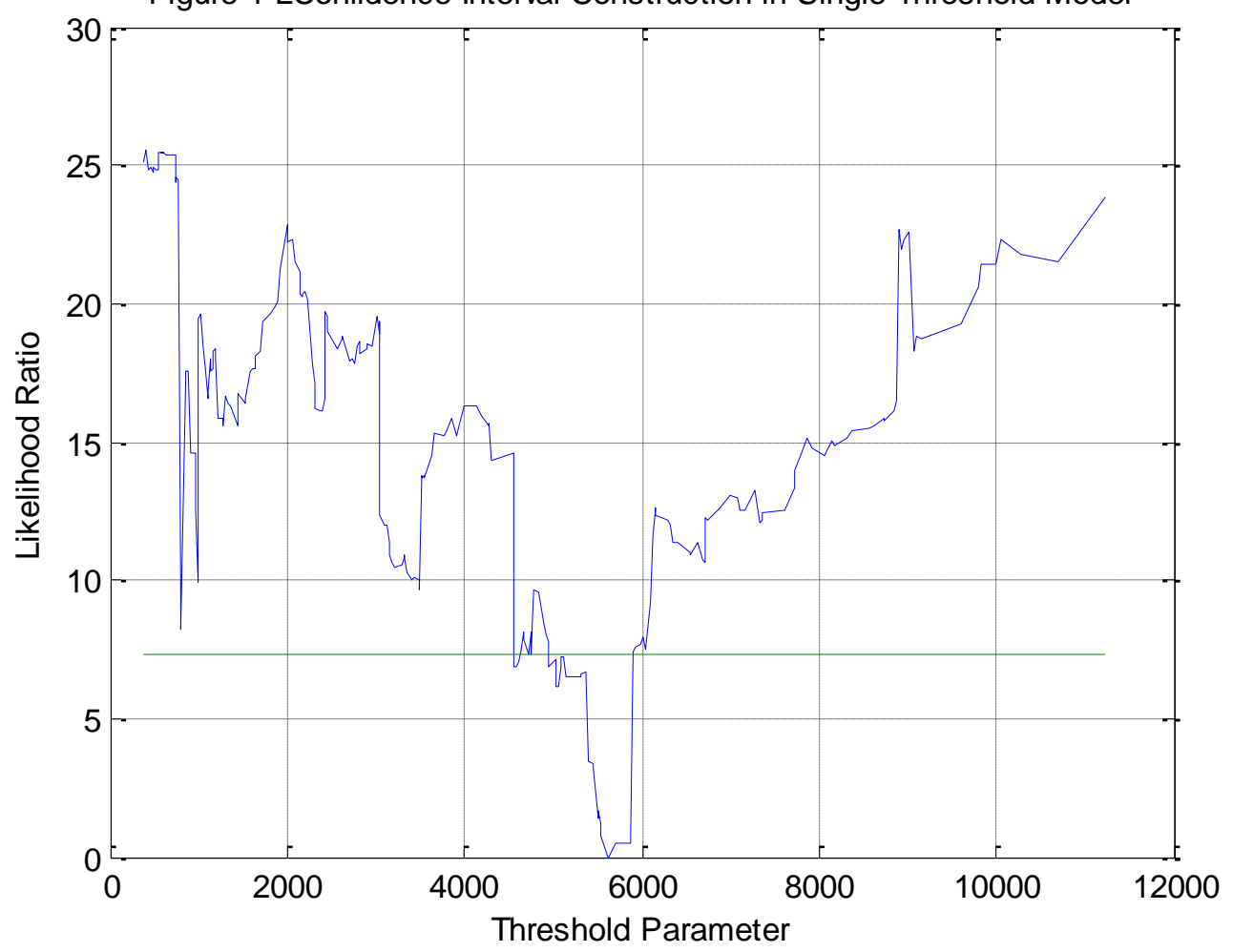

Table 3 : Estimation of coefficients

\begin{tabular}{|c|c|c|c|c|c|}
\hline 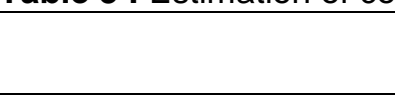 & Coefficient & OLS SE & $\mathrm{T}(\mathrm{OLS})$ & $\begin{array}{c}\text { White } \\
\text { SE }\end{array}$ & T(White) \\
\hline GDP & 0,665 & 0,224 & $2,96^{* * *}$ & 0,234 & $2,84^{* * *}$ \\
\hline EDUC & 0,018 & 0,006 & $3^{\star \star \star}$ & 0,006 & $3^{\star \star \star}$ \\
\hline $\mathrm{EF}$ & 0,056 & 0,046 & 1,21 & 0,035 & 1,6 \\
\hline POP & 0,437 & 0,254 & $1,72^{*}$ & 0,254 & $1,72^{*}$ \\
\hline FDI I(GDP $<=5620,486)$ & $-0,057$ & 0,027 & $-2,11^{* *}$ & 0,019 & $-3^{\star \star \star}$ \\
\hline FDI I (GDP > 5620,486) & 0,094 & 0,03 & $3,13^{\star \star *}$ & 0,025 & $3,76^{* \star *}$ \\
\hline
\end{tabular}

Table 3 reports estimation results of the panel threshold model. It shows that FDI affects significantly the level of innovation. However, this impact is different depending on the regime. In the first regime, where the level of technological development is less than or equal to the threshold value (5620,486 PPP), the effect of FDI is negative and significant. In the second regime where countries are characterized by a high level of economic development, the effect is positive and significant at $1 \%$. In the first class, when the share in GDP of inflows of foreign investments increases by $1 \%$, the number of patent applications filed in the USPTO decreases by $0,057 \%$. On the other hand, in the second regime, an increase of $1 \%$ in FDI inflows allows an increase of $0,094 \%$ in number of patent applications. Thus, we find that only countries with a high level of economic development can benefit in terms of innovation from the increase in the level of foreign direct investment. As expected, our results confirm the nonlinear relationship between the foreign investments and the level of technological innovation. They are consistent with those of Sinani and Klaus (2004) and 
Monastiriotis and Alegria (2011). These results highlight that advantages of foreign direct investments are not automatic. They require an initial outlay in terms of investment in machinery, tools and human capital training. Absorptive capacity of host countries is very crucial to benefit from advanced technology and other assets of foreign firms.

For the control variables, the GDP per capita, the education level and the size of the country have a positive and significant impact on innovation. The institutional framework is not significant. We find that the effect of GDP per capita is positive and significant. This result is consistent with that found by Furman et. al. (2002) and Hu and Mathews (2005). Interpreting the coefficient as elasticity, a $10 \%$ increase in GDP is associated with a $4,66 \%$ rise in international patent output. As suggested by proponents of endogenous growth, a country's existing level of technological sophistication plays a key role in determining innovative output.

The coefficient for EDUC is positive $(0,018)$ and significant. This result highlights the importance of the stock of human capital for innovation. Population has a positive and significant sign. This result shows the presence of scale economies.

In contrast to these findings, the impact of the economic freedom index is not significant. This implies that the institutional environment in developing countries is unfavourable to innovative activity.

\section{Conclusion}

The purpose of this paper is to examine the effect of foreign direct investment on innovation in developing counries. The estimation of panel threshold model shows the presence of non linear effects in the relationship between FDI and innovation. We find a threshold value of technological development below which FDI have a negative impact on innovation and above which FDI have a significant positive impact on innovation. The results imply that the strength of the FDI effect on innovation capabilities depends upon the absorptive capacity of and the complementary assets in the domestic sector.

The present study has important implications. First, the significant presence of threshold effects calls into question the relevance of any econometric specification assuming a linear relationship between FDI and innovation. Second, it is not enough for economic policy to attract foreign investments, it is still necessary to build in domestic firms an absorptive capacity in order to enjoy the benefits of multinational firms.

\section{References}

Aghion, P. and Howitt, P. (1998). Endogenous growth theory, The MIT Press, Cambridge, Massachusetts.

Aghion, P. and Howitt, P. (1992). 'A model of growth through creative destruction', Econometrica, vol. 60, pp. 323-351.

Aghion, P. (2004). 'Growth and development: A Schumpeterian approach', Annals of Economics and Finance, vol. 5, pp. 1-25.

Aitken, B.J. and Harrison, A. (1999). 'Do domestic firms benefit from direct foreign investment? Evidence from Venezuela', The American Economic Review, vol. 89, no. 3, pp. 605-618.

Altenburg, T. (2000). Linkages and spillovers between transnational corporations and small and medium-sized enterprises in developing countries-opportunities and policies, in UNCTAD (Ed.), TNC-SME Linkages for development; Issues-experiences-best practices, New York: United Nations.

Berger, M. and Diez, J.R. (2008). 'Can host innovation systems in late industrializing countries benefit from the presence of transnational corporations? Insights from Thailand's manufacturing industry', European Planning Studies, vol. 16, no. 8, pp. 1047-1074. 
Blomstrom, M. and Kokko, A. (2002). FDI and human capital: A research agenda. Technical Papers OECD Development Centre no. 195, available from http://www.oecd.org/dev/1950227.pdf

Branstetter, L. G. (2001). 'Are knowledge spillovers international or intranational in scope? Microeconometric evidence from the US and Japan', Journal of International Economics, vol. 53, pp. 53-79.

Chen, Y. (2007). 'Impact of direct foreign investment on regional innovation capability: A case of China', Journal of Data Science, vol. 5, pp. 577-596.

Chen, Y. and Puttitanun, T. (2005). 'Intellectual property rights and innovation in developing countries', Journal of Development Economics, vol. 78, pp. 474-493.

Cheung, K.Y. and Lin, P. (2004). 'Spillover effects of FDI on innovation in China: Evidence from provincial data', China Economic Review, vol. 15, no. 1, pp. 25-44.

Cohen, W.M. and Levinthal, D.A. (1990). 'Absorptive capacity: A new perspective on learning and innovation', Administrative Science Quarterly, vol. 35, pp. 128-152.

Driffield, N. (1999). 'Determinants of entry and exit in the foreign owned sector of UK manufacturing', Applied Economics Letters, vol. 6, pp. 153-156.

Fagerberg, J., Martin, S. and Mark, K. (2007). 'The competitiveness of nations: Why some countries prosper while others fall behind', World Development, vol. 35, pp. 1595-1620.

Furman, J.L., Porter, M.E. and Stern, S. (2002). 'The determinants of national innovative capacity', Research Policy, vol. 31, pp. 899-933.

Geroski, P.A. (1989). 'Entry, innovation and productivity growth', Review of Economics and Statistics, vol. 71, pp. 572-578.

Grilliches, Z. (1990). 'Patent statistics as economic indicators: A survey', Journal of Economic Literature, vol. 28, pp. 1646-1661.

Gumbau-Albert, M. and Maudos, J. (2009). 'Patents, technological inputs and spillovers among regions', Applied Economics, vol. 41, no. 12, pp. 1473-1486.

Hansen, B.E. (1999). 'Threshold effects in non dynamic panels: estimation, testing and inference', Journal of Econometrics, vol. 93, pp. 345-368.

Haskel, J.E., Pereira, S.C. and Slaughter, M.J. (2007). 'Does inward foreign direct investment boost the productivity of domestic firms?', Review of Economics and Statistics, vol. 2007, no. 89, pp. 482-496.

Hayter, R. and Han, S. (1998). 'Reflections on China's open policy towards direct foreign investment', Regional Studies, vol. 32, pp. 1-16.

Hu, M.C. and Mathews, J.A. (2005). 'National innovative capacity in East Asia', Research Policy, vol. 34, pp. 1322-1349.

Keller, W. and Yeaple, S.R. (2009). 'Multinational enterprises, international trade, and productivity growth: Firm level evidence from the United States', Review of Economics and Statistics, vol. 91, pp. 821-831.

Kokko, A. (1996). 'Productivity spillovers from competition between local firms and foreign affiliates', Journal of International Development, vol. 8, pp. 517-530.

Lerner, J. (2002). '150 years of patent protection', American Economic Review, vol. 92, no. 2 May, pp. 221-225.

Mahagaonkar, P. (2008). Corruption and innovation: a grease or sand relationship?, in Z.J., Acs, and D.B. Audretsh (Eds.), Money and ideas. Four studies on finance, innovation and the business life cycle.

Monastiriotis, V. and Alegria, R. (2011). 'Origin of FDI and Intra-Industry Domestic Spillovers: The Case of Greek and European FDI in Bulgaria', Review of Development Economics, vol. 15, no. 2, pp. 2326-339.

Pritchett, L. (1996). Population growth, factor accumulation and productivity. Policy Research Working Paper no. 1567, available from http://www.hks.harvard.edu/fs/lpritch/Population\%20\%20docs/populationfactoraccumulatio $\underline{\text { n.pdf }}$ 
Romer, P.M. (1990). 'Endogenous technological change', Journal of Political Economy, vol. 98, pp. 71-102.

Sala-i-Martin, X. (2002). 15 Years of New Growth Economics: What Have We Learnt? Central Bank of Chile Working Paper no. 172, available from http://www2.econ.iastate.edu/tesfatsi/negrowth.salaimartin.pdf

Sinani, E. and Klaus M. (2004). 'Spillovers of Technology Transfer from FDI: The Case of Estonia', Journal of Comparative Economics, vol. 32, pp. 445-66.

Sjoholm, F. (1999). 'Productivity growth in Indonesia: the role of regional characteristics and direct foreign investment', Economic Development and Cultural Change, vol. 47, no. 3, pp. 559-584.

Tebaldi, E. and Elmslie, B. (2013). 'Does institutional quality impact innovation? Evidence from cross-country patent grant data', Applied Economics, vol. 45, pp. 887-900.

Ulku, H. (2007). 'R\&D, innovation and output: Evidence from OECD and non OECD countries', Applied Economics, vol. 39, no. 3, pp. 291-307.

UNCTAD (2001). World Investment Report 2001: Promoting Linkages. New York and Geneva: United Nations, available from http://unctad.org/en/Docs/wir2001 en.pdf

Varsakelis, N.C. (2006). 'Education, political institutions and innovative activity: A cross-country empirical investigation', Research Policy, vol. 35, pp. 1083-1090.

$\mathrm{Xu}$, B. (2000). 'Multinational Enterprises, Technology Diffusion, and Host Country Productivity Growth', Journal of Development Economics, vol. 62, pp. 477-493.

Yokota, K. and Tomohara, A. (2010). 'Modeling FDI-Induced Technology Spillovers', International Trade Journal, vol. 24, no. 1, pp. 5-34.

\section{Bio-note}

Kamilia Loukil is a researcher at the Faculty of Economics and Management of Sfax,Tunisia. She has a Ph.D. in Economics at University of Sfax. Her main interests refer to innovation, innovation policy and industrial policy in developing and emerging countries. 